\title{
IRREDUCIBLE CONGENITAL DISLOCATION OF THE KNEE
}

\author{
AETIOLOGY AND MANAGEMENT
}

\author{
M. J. BELL, R. M. ATKINS, W. J. W. SHARRARD
}

From the Children's Hospital, Sheffield

\begin{abstract}
We report nine cases of irreducible congenital dislocation of the knee which were treated by early operation with good results. All were resistant to conservative measures and operation was performed at an average age of nine months. The essential abnormality was a short quadriceps muscle together with subluxation of the hamstring muscles to lie anterior to the axis of knee flexion. The quadriceps tendon was lengthened by VY-plasty and in six cases additional length was gained by proximal mobilisation of the muscle. After operation all the patients were able to walk.
\end{abstract}

Congenital hyperextension deformities of the knee comprise a spectrum of lesions including simple hyperextension, subluxation and complete dislocation (Finder 1964; Curtis and Fisher 1969; Jacobsen and Vopalecky 1985). The incidence of true dislocation is reported to be 0.017 per 1000 live births (Jacobsen and Vopalecky 1985). Several authors report an association with other congenital deformities including congenital dislocation of the hip and congenital foot deformities. Dislocation of the knee has been described in children with arthrogryposis, in those with spina bifida and in others suffering from joint laxity syndromes.

This paper reports nine complete dislocations of the knee in five children, including their surgical management and its results. A consideration of their clinical and pathological features and a review of the literature allows the possible causes of the irreducible dislocations to be discussed.

\section{MATERIAL}

There were five children, four girls and one boy, with nine dislocated knees (Table I). All presented at birth with a recurvatum deformity. It was not possible in any case to flex the knee beyond zero degrees of extension at birth, but in one $20^{\circ}$ of flexion was achieved before operation. All demonstrated at least $45^{\circ}$ of hyperexten-

M. J. Bell, FRCS, Senior Orthopaedic Registrar

Sheffield Children's Hospital, Western Bank, Sheffield S10 2TH, England.

R. M. Atkins, FRCS, Clinical Lecturer

Nuffield Department of Orthopaedic Surgery, Nuffield Orthopaedic Centre, Oxford, England.

W. J. W. Sharrard, MD, ChM, FRCS, Consultant Orthopaedic Surgeon and Professor Associate

140 Manchester Road, Sheffield S10 5DL, England.

Requests for reprints should be sent to Mr M. J. Bell.

(C) 1987 British Editorial Society of Bone and Joint Surgery $0301-620 \mathrm{X} / 87 / 3088 \$ 2.00$ sion. A deep anterior transverse skin fold was found in all cases and femoral condyles that were prominent and palpable in the popliteal fossa. The patella was deeply placed and usually impalpable. There was a characteristic clinical appearance when the child lay supine (Fig. 1): the fixed hyperextension of the knee combined with the weight of the leg allowed the hip to fall into lateral rotation, giving a spurious appearance of valgus deformity of the knee. Radiographic examination confirmed the presence of dislocation with the tibia anterior to the femoral condyles and displaced proximally (Fig. 2).

One patient with arthrogryposis had bilateral congenital dislocation of the hip and congenital foot deformities in addition to the bilateral dislocation of the knee. The other four children all showed features of ligamentous laxity as defined by Carter and Wilkinson (1964) with at least three sites other than the knee showing hyperextensibility. One child with joint laxity had a bilateral dislocation of the hip which responded to

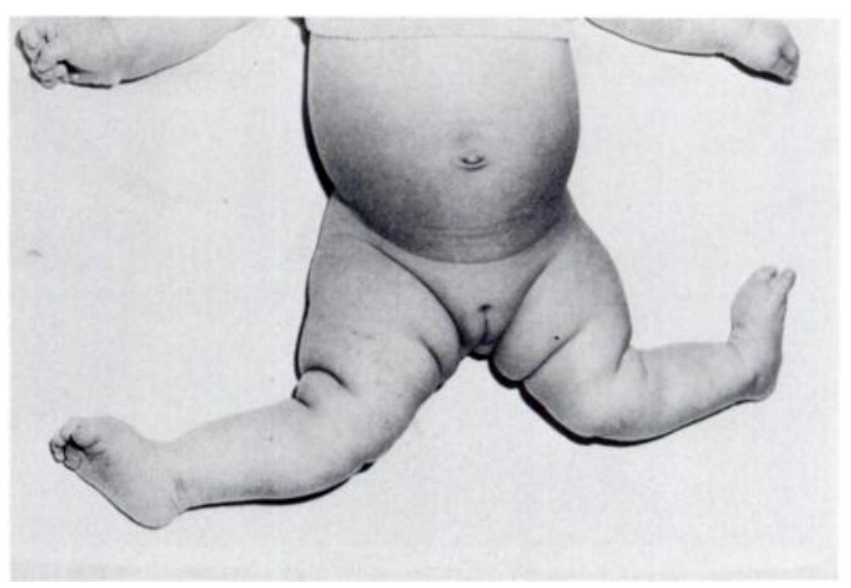

Fig. 1

The characteristic appearance of congenital dislocation of the knees. 
Table I. Details of the five children with dislocated knees

\begin{tabular}{|c|c|c|c|c|c|c|c|}
\hline Patient & Sex & Aetiology & Side & $\begin{array}{l}\text { Associated } \\
\text { abnormalities }\end{array}$ & $\begin{array}{l}\text { Birth } \\
\text { position }\end{array}$ & $\begin{array}{l}\text { Age at } \\
\text { operation } \\
\text { (months) }\end{array}$ & $\begin{array}{l}\text { Type of } \\
\text { operation }\end{array}$ \\
\hline 1 & $\mathrm{~F}$ & $\begin{array}{l}\text { Ligament } \\
\text { laxity }\end{array}$ & $\begin{array}{l}\mathbf{R} \\
\mathbf{L}\end{array}$ & $\begin{array}{l}\text { Bilateral } \\
\text { CDH }\end{array}$ & $\begin{array}{l}\text { Extended } \\
\text { breech }\end{array}$ & $\begin{array}{l}11 \\
11\end{array}$ & VY-plasty \\
\hline 2 & $\mathrm{~F}$ & $\begin{array}{l}\text { Ligament } \\
\text { laxity }\end{array}$ & $\mathbf{L}$ & & $\begin{array}{l}\text { Extended } \\
\text { breech }\end{array}$ & 2 & VY-plasty \\
\hline 3 & $F$ & $\begin{array}{l}\text { Ligament } \\
\text { laxity }\end{array}$ & $\begin{array}{l}\mathbf{R} \\
\mathbf{L}\end{array}$ & $\begin{array}{l}\text { Mosaic } \\
\text { Down's } \\
\text { syndrome }\end{array}$ & $\begin{array}{l}\text { Extended } \\
\text { breech }\end{array}$ & $\begin{array}{r}7 \\
11\end{array}$ & $\begin{array}{l}\text { VY-plasty and } \\
\text { quadriceps } \\
\text { mobilisation }\end{array}$ \\
\hline 4 & $\mathbf{M}$ & $\begin{array}{l}\text { Ligament } \\
\text { laxity }\end{array}$ & $\begin{array}{l}\mathbf{R} \\
\mathrm{L}\end{array}$ & $\begin{array}{l}\text { Valgus } \\
\text { feet }\end{array}$ & $\begin{array}{l}\text { Vertex } \\
\text { twin }\end{array}$ & $\begin{array}{l}4 \\
7\end{array}$ & $\begin{array}{l}\text { VY-plasty and } \\
\text { quadriceps } \\
\text { mobilisation }\end{array}$ \\
\hline 5 & $F$ & Arthrogryposis & $\begin{array}{l}\text { R } \\
\text { L }\end{array}$ & $\begin{array}{l}\text { Bilateral } \\
\text { CDH, } \\
\text { valgus feet }\end{array}$ & $\begin{array}{l}\text { Extended } \\
\text { breech }\end{array}$ & $\begin{array}{l}13 \\
17\end{array}$ & $\begin{array}{l}\text { VY-plasty and } \\
\text { quadriceps } \\
\text { mobilisation }\end{array}$ \\
\hline
\end{tabular}

conservative management, another had quite marked valgus flat feet. A third child suffered from a mosaic Down's syndrome which is associated with joint laxity.

All knees had failed to respond to conservative measures such as manual manipulations and serial plasters. Excessively vigorous attempts to correct the dislocations were felt to be inadvisable because of the danger of damaging the epiphyses (Jacobsen and Vopalecky 1985) or the articular surfaces. A decision to perform an operative release and open reduction was made during the first year of life. The operation was performed at a mean age of nine months, the youngest being two months and the oldest 17 months.

\section{OPERATION}

The essential abnormality needing operative correction was severe shortness of the quadriceps. It needed to be elongated to almost double its length if reduction was to be achieved with a useful range of knee flexion. The operation was performed without a tourniquet, with the patient in a semi-lateral position and a sandbag under the

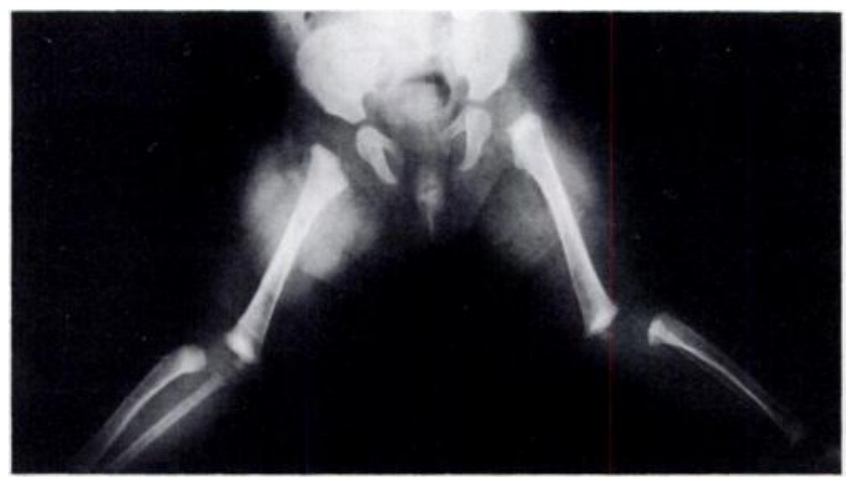

Fig. 2

Typical radiographic features, the tibia lying in front of the femur. The right leg demonstrates the lateral rotation of the hip. buttock. The incision extended from above the greater trochanter to the anterior border of the tibia. The fascia lata was split along its whole length. The mass of the quadriceps muscle was mobilised from the femoral shaft to allow it to be displaced distally as far as the tension on the branches of the femoral nerve would allow (Fig. 3). If necessary, the rectus femoris tendon was divided proximally.

The quadriceps tendon and the patella were adherent through a mass of fibrous tissue to the anterior aspect of the lower end of the femur, the suprapatellar pouch being obliterated. The quadriceps tendon together with the tendon of rectus femoris was lengthened using a long inverted $\mathrm{V}$-incision as described by Curtis and Fisher (1969) (Fig. 4). This enabled the distal part of the quadriceps mechanism with the patella and patellar tendon to be mobilised distally. The medial and lateral collateral ligaments and the medial hamstring tendons were found to be displaced over the eminences of the femoral condyles and lay anterior to the axis of flexion of the joint. The anterior cruciate ligament was always present but elongated, thick and wide. None of these

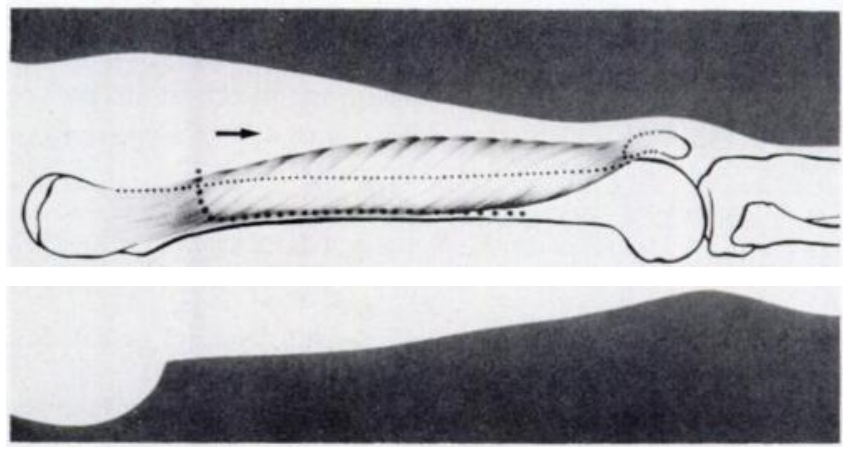

Fig. 3

Diagram showing the lateral approach required to mobilise the whole quadriceps muscle mass. The arrow indicates the direction of the muscle slide. 
Table II. Results of operative treatment

\begin{tabular}{|c|c|c|c|c|c|c|c|c|c|}
\hline \multirow[b]{2}{*}{ Patient } & \multirow[b]{2}{*}{ Side } & \multirow{2}{*}{\multicolumn{2}{|c|}{$\begin{array}{l}\text { Pre-op ROM } \\
\text { (active and } \\
\text { pasaive) }\end{array}$}} & \multicolumn{2}{|c|}{ ROM at review } & \multirow[b]{2}{*}{ Stability } & \multirow{2}{*}{$\begin{array}{l}\text { Quadriceps } \\
\text { power }\end{array}$} & \multirow[b]{2}{*}{ Function } & \multirow[b]{2}{*}{ Follow-up } \\
\hline & & & & Pasodve & Active & & & & \\
\hline 1 & $\begin{array}{l}\mathbf{R} \\
\mathbf{L}\end{array}$ & $\begin{array}{l}-45^{\circ} \text { to } \\
-45^{\circ} \text { to }\end{array}$ & $\begin{array}{l}0^{\circ} \\
0^{\circ}\end{array}$ & $\begin{array}{l}0^{\circ} \text { to } 150^{\circ} \\
0^{\circ} \text { to } 150^{\circ}\end{array}$ & $\begin{array}{l}20^{\circ} \text { to } 150^{\circ} \\
30^{\circ} \text { to } 150^{\circ}\end{array}$ & $\begin{array}{l}\text { Positive ant. drawer } \\
\text { Stable }\end{array}$ & $\begin{array}{l}5 \\
4+\end{array}$ & Walking & 17 years \\
\hline 2 & $\mathbf{L}$ & $-30^{\circ}$ to & $25^{\circ}$ & $0^{\circ}$ to $100^{\circ}$ & $10^{\circ}$ to $100^{\circ}$ & Stable & 4 & Walking & 12 months \\
\hline 3 & $\begin{array}{l}\mathbf{R} \\
\mathbf{L}\end{array}$ & $\begin{array}{l}-35^{\circ} \text { to } \\
-30^{\circ} \text { to }\end{array}$ & $\begin{array}{r}-5^{\circ} \\
0^{\circ}\end{array}$ & $\begin{array}{ll}0^{\circ} \text { to } & 80^{\circ} \\
0^{\circ} \text { to } & 75^{\circ}\end{array}$ & $\begin{array}{l}30^{\circ} \text { to } 80^{\circ} \\
15^{\circ} \text { to } 75^{\circ}\end{array}$ & $\begin{array}{l}\text { Stable } \\
\text { Stable }\end{array}$ & $\begin{array}{l}4 \\
4\end{array}$ & Walking & 34 months \\
\hline 4 & $\begin{array}{l}\mathbf{R} \\
\mathbf{L}\end{array}$ & $\begin{array}{l}-30^{\circ} \text { to } \\
-25^{\circ} \text { to }\end{array}$ & $\begin{array}{l}0^{\circ} \\
0^{\circ}\end{array}$ & $\begin{array}{l}0^{\circ} \text { to } 100^{\circ} \\
0^{\circ} \text { to } 95^{\circ}\end{array}$ & $\begin{array}{l}0^{\circ} \text { to } 100^{\circ} \\
0^{\circ} \text { to } 95^{\circ}\end{array}$ & $\begin{array}{l}\text { Stable } \\
\text { Stable }\end{array}$ & $\begin{array}{l}4+ \\
4+\end{array}$ & Walking & $\begin{array}{l}33 \text { months } \\
30 \text { months }\end{array}$ \\
\hline 5 & $\begin{array}{l}\mathbf{R} \\
\mathbf{L}\end{array}$ & $\begin{array}{l}-30^{\circ} \text { to } \\
-25^{\circ} \text { to }\end{array}$ & $\begin{array}{l}-10^{\circ} \\
-10^{\circ}\end{array}$ & $\begin{array}{l}0^{\circ} \text { to } 80^{\circ} \\
0^{\circ} \text { to } 30^{\circ}\end{array}$ & $\begin{array}{l}10^{\circ} \text { to } 80^{\circ} \\
10^{\circ} \text { to } 30^{\circ}\end{array}$ & $\begin{array}{l}\text { Stable } \\
\text { Stable }\end{array}$ & $\begin{array}{l}4 \\
4\end{array}$ & Walking & $\begin{array}{l}18 \text { months } \\
15 \text { months }\end{array}$ \\
\hline
\end{tabular}

ROM, range of movement

Negative figures signify hyperextension

structures impeded reduction of the dislocation. The shape of the femoral and tibial condyles was surprisingly normal and the menisci were present. The knee could be flexed to $90^{\circ}$ but if this was attempted the quadriceps tendon was too short to suture and the skin became tight. When the knee was extended to $20^{\circ}$ of flexion, it tended to redislocate. The quadriceps tendon was sutured to give as much length as possible with a mean position of $40^{\circ}$ of knee flexion.

The fascia lata and skin were closed over suction drainage. No attempt was made to suture the knee capsule. The knee was immobilised in plaster in $40^{\circ}$ of flexion for three weeks; at that time the plaster was changed with the knee flexed a further $20^{\circ}$ to $30^{\circ}$, depending on the condition of the skin overlying the patella. The plaster was removed at six weeks and the knee was allowed to mobilise.

\section{RESULTS}

The patients were examined to determine the range of knee movement, stability, power of extension and functional ability. Follow-up was from one to 17 years after operation; if the two knees in the one patient followed up for 17 years are excluded, the remaining seven knees had a mean follow-up of 24 months. The results are shown in Table II.

All the patients were able to walk. An extensor lag of up to $30^{\circ}$ was present in all patients except one; in one girl this had caused a problem needing bilateral reefing of the quadriceps tendon two years before our review. This patient had only had a VY-plasty of the quadriceps tendon without proximal mobilisation of the quadriceps. The tenous tendon that resulted stretched so as to cause an increasing extensor lag which was corrected by secondary reefing. At final follow-up she was walking independently, without splints, but she still had an extensor lag of $30^{\circ}$.

All the knees were stable except one which had a
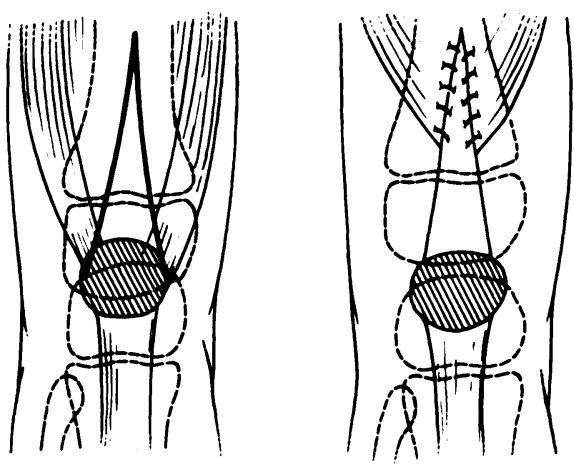

Fig. 4

The Curtis and Fisher VY-plasty. (Redrawn from Curtis and Fisher 1969, and reproduced with permission.)

positive anterior drawer sign. The quadriceps power in all cases was Grade 4 or greater. Flexion of $75^{\circ}$ or more was achieved in eight of the nine knees.

In one patient the knee was placed in $60^{\circ}$ of flexion immediately after operation. Excessive skin tension led to skin necrosis and breakdown, but secondary healing occurred.

\section{DISCUSSION}

Several series in the literature report a spectrum of hyperextension deformities varying from simple hyperextension to complete dislocation. Some authors (Finder 1964; Laurence 1967; Curtis and Fisher 1969; Jacobsen and Vopalecky 1985) have used a grading system to classify these hyperextension deformities; however, it is doubtful whether this grading provides a reliable indication of the likely response to conservative treatment. Mayer (1912-13) reporting on 68 patients found that a cure was achieved by non-operative means in $81 \%$ of those treated before three months of age. Nogi and MacEwen (1982) successfully treated all but three of 17 patients (excluding those with arthrogryposis or neuromuscular disorders); they used manipulation and serial plasters or a Pavlik harness applied immediately after 
birth. However, in both these series it is not clear whether the patient had a dislocation or a simple hyperextension deformity. It may be that those that responded to conservative management were simple hyperextension deformities or subluxations, and those that failed to respond were the true dislocations. This could explain why some failures occurred with conservative treatment, even when this was begun early (Nogi and MacEwen 1982; Austwick and Dandy 1983; Jacobsen and Vopalecky 1985).

Our experience and a study of the literature leads us to believe that unbalanced muscle action is the common factor in both congenital dislocations associated with neuromuscular lesions and those with laxity syndromes but apparently normal muscles who failed to respond to conservative treatment.

Primary muscle imbalance. In patients suffering from arthrogryposis (Brown, Robson and Sharrard 1980) or congenital neuromuscular lesions such as myeolomeningocele (Sharrard 1979) weakness of knee flexors in the presence of strong extensors before birth leads to differential muscle growth with shortening of the stronger quadriceps. This leads to a dislocation of the knee by a similar mechanism to that which occurs in paralytic dislocation of the hip (Sharrard 1964).

Secondary muscle imbalance. Several authors (Niebauer and King 1960; Curtis and Fisher 1969) have noted the perverted action of the hamstring tendons when they are displaced forward by the anterior dislocation of the tibia; they cease to be knee flexors and become secondary extensors. Katz, Grogono and Soper (1967) have shown that the anatomical configuration of the fetal knee allows for hyperextension. If there has been marked ligamentous laxity in utero, hyperextension of the knee can occur by the same mechanism as that described by Wilkinson (1985) as a cause of congenital dislocation of the hip when the fetus is in the extended breech position.

In this hyperextended position, if the hamstrings subluxate anterior to the axis of flexion of the joint, they become perverted knee extensors. A secondary muscle imbalance develops resulting in a similar differential growth shortening of the quadriceps to that found in primary imbalance and with the consequent difficulty in obtaining reduction by conservative means.

The pathological findings at operation in our series have been almost identical with those found by Curtis and Fisher (1969). We did not find an absent anterior cruciate ligament as described by Katz et al. (1967), or an abnormal sloping tibial articular surface, both of which must be considered to be late secondary phenomena. The posterior cruciate ligament did not seem to be tight or need to be divided to obtain reduction as suggested by Austwick and Dandy (1983). The results of operative treatment of such severe and resistant cases as those in our series are comparable with those of Curtis and Fisher (1969) and others, namely a liability to a persistent extensor lag, but with adequate walking function (Figs 5

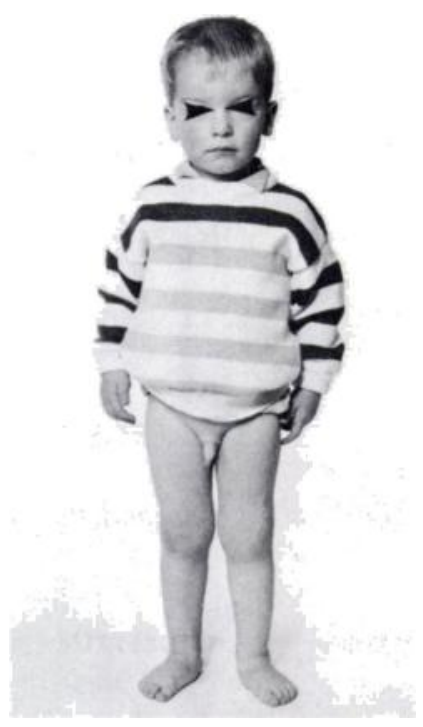

Fig. 5

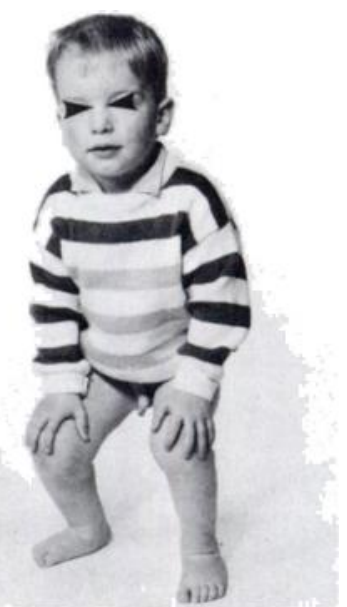

Fig. 6
The clinical result three years after surgery; he stands normally and both knees have reasonable flexion.

and 6). The extensor lag is explained by the initial lack of growth in the quadriceps muscle which produces a limited excursion with muscle contraction. We found that the extensor lag was improving in three of our patients, suggesting that muscle growth was occurring and the excursion increasing.

\section{REFERENCES}

Austwick DH, Dandy DJ. Early operation for congenital subluxation of the knee. J Pediatr Orthop 1983;3:85-7.

Brown LM, Robson MJ, Sharrard WJW. The pathophysiology of arthrogryposis multiplex congenita neurologica. J Bone Joint Surg $[B r] 1980 ; 62-B: 291-6$.

Carter C, Wilkinson J. Persistent joint laxity and congenital dislocation of the hip. J Bone Joint Surg [Br] 1964;46-B:40-5.

Curtis BH, Fisher RL. Congenital hyperextension with anterior subluxation of the knee: surgical treatment and long-term observations. J Bone Joint Surg [Am] 1969;51-A :255-9.

Finder JG. Congenital hyperextension of the knee. J Bone Joint Surg [Br] 1964;46-B:783.

Jacobsen K, Vopalecky F. Congenital dislocation of the knee. Acta Orthop Scand 1985;56:1-7.

Katz MP, Grogono BJS, Soper KC. The etiology and treatment of congenital dislocation of the knee. J Bone Joint Surg [Br] 1967; 49-B:112-20.

Laurence M. Genu recurvatum congenitum. J Bone Joint Surg [Br] 1967;49-B:121-34.

Mayer L. Congenital anterior subluxation of the knee: description of a new specimen, summary of the pathology of the deformity and discussion of its treatment. Am J Orthop Surg 1912-13;10:441-37.

Niebauer JJ, King DE. Congenital dislocation of the knee. J Bone Joint Surg [Am] 1960;42-A:207-25.

Nogi J, MacEwen GD. Congenital dislocation of the knee. J Pediatr Orthop 1982;2:509-13.

Sharrard WJW. Paediatric orthopaedics and fractures. 2nd ed. Oxford, etc: Blackwell Scientific Publications, 1979.

Sharrard WJW. Posterior iliopsoas transplantation in the treatment of paralytic dislocation of the hip. J Bone Joint Surg [Br] 1964; 46-B:426-44.

Wilkinson JA. Congenital displacement of the hip joint. Berlin etc: Springer-Verlag, 1985. 